\title{
INHA wt Allele
}

National Cancer Institute

\section{Source}

National Cancer Institute. INHA wt Allele. NCI Thesaurus. Code C52046.

Human INHA wild-type allele is located within 2q33-q36 and is approximately $3 \mathrm{~kb}$ in length. This allele, which encodes inhibin alpha chain protein, is involved in the inhibition of follitropin secretion in the pituitary gland and plays a role in the regulation of diverse cellular functions. 